\title{
Study Of Needs And Availability Of Clean Water, Palangka Raya City
}

\author{
Studi Kebutuhan Dan Ketersedian Air Bersih Kota Palangka Raya
}

\author{
Airways Parlindungan Siahaan \\ Program Studi Pendidikan Teknik Mesin, FKIP, UPR \\ Kampus Unpar Tunjung Nyaho, Jl. H. Timang, 73111A
}

\begin{abstract}
Palangka Raya City, one of the candidates for Indonesia's capital city, has made Palangka Raya develop very rapidly. The development of the City encourages an increase in population. Therefore, planning for clean water needs for Palangka Raya City is needed. Calculation of projected population growth using the Least Square Method. Calculation of domestic clean water needs and non-domestic water needs using the standards of the Directorate General of Human Settlements. In addition to calculating the need for clean water, calculating the availability of water until 2037. Water quality distribution of PDAM Palangka Raya City has met the requirements for class B standards, namely water that can be used as raw material for drinking water. PDAM Kota Palangka Raya has an existing intake of 200 liters / second, according to projection calculations using the linear regression method it is found that the need for clean water by 2037 is 1060.2 liters / second and the availability of water is 2877 liters / second until 2037, it can be said to in 2037 the need for clean water is fulfilled.
\end{abstract}

Keywords: Population Projection, Clean Water Needs, PDAM Kota Palangka Raya

Kota Palangka Raya salah satu calon Ibukota negara Indonesia hal ini membuat Palangka Raya berkembang menjadi sangat pesat. Berkembangnya Kota mendorong bertambahnya jumlah penduduk. Oleh karena itu diperlukan perencanaan kebutuhan air bersih untuk Kota Palangka Raya. Perhitungan proyeksi pertumbuhan penduduk menggunakan metode Metode Least Square. Perhitungan kebutuhan air bersih domestik dan kebutuhan air non domestik menggunakan standar dari Ditjen Cipta Karya. Selain perhitungan kebutuhan air bersih, menghitung ketersedian air sampai tahun 2037. Kualitas air distribusi PDAM Kota Palangka Raya sudah memenuhi syarat untuk standar golongan B yaitu air yang dapat digunakan sebagai bahan baku air minum. PDAM Kota Palangka Raya memiliki eksisting intake sebesar 200 liter/detik, menurut perhitungan proyeksi dengan menggunakan metode regresi linier didapat kebutuhan air bersih sampai tahun 2037 adalah sebesar 1060,2 liter/detik dan ketersedian air 2877 liter/detik sampai tahun 2037, bisa dikatakan untuk tahun 2037 kebutuhan air bersih terpenuhi.

Kata Kunci: Proyeksi Penduduk, Kebutuhan Air Bersih, PDAM Kota Palangka Raya

\section{PENDAHULUAN}

Air bersih merupakan air yang digunakan untuk keperluan sehari-hari dan akan menjadi air minum setelah dimasak terlebih dahulu. Sedangkan air minum adalah air yang mengalami proses pengolahan atau tanpa proses pengolahan yang memenuhi syarat kesehatan dan dapat langsung diminum. Air minum aman bagi kesehatan apabila memenuhi persyaratan fisika, mikrobiologis, kimiawi, dan radioaktif. Namun kualitas air yang baik ini tidak selamanya tersedia di alam sehingga diperlukan upaya perbaikan, baik itu secara sederhana maupun modern.

Tujuan dari keberadaan PDAM yaitu memberikan pelayanan kepada masyarakat terhadap penyediaan sarana dan prasarana air bersih yang berkualitas, dan memenuhi persyaratan kesehatan. Pengelolaan pelayanan air bersih untuk kebutuhan masyarakat Kota Palangka Raya dilaksanakan oleh PDAM Kota Palangka Raya yang merupakan perusahaan milik pemerintah Kota Palangka Raya. Sama seperti PDAM di kota-kota lain di Indonesia, PDAM kota Palangka Raya juga mempunyai masalah yang sama yaitu tingkat pelayanan (coverage level) yang rendah dan tingkat kehilangan air (uncounted water) yang tinggi. Tingkat kebocoran Perusahaan Air Minum Kota Palangka Raya berkisar antara 20-30\%.

Di daerah perkotaan khususnya Palangka Raya air bersih dilakukan dengan sistem perpipaan dan non perpipaan. Sistem perpipaan dikelola oleh Perusahaan Daerah Air Minum (PDAM) dan sistem non perpipaan dikelola oleh masyarakat baik secara individu maupun kelompok.

Kota Palangka Raya mempunyai luas wilayah $2.678,41 \mathrm{~km}^{2}$ dibagi ke dalam 5 (lima) Kecamatan yaitu Kecamatan Pahandut $(117,25)$, Sebangau $\left(583,50 \mathrm{~km}^{2}\right)$, Jekan Raya $\left(352,62 \mathrm{~km}^{2}\right)$, Bukit Batu $\left(572 \mathrm{~km}^{2}\right)$ dan Rakumpit (1.053,14 $\left.\mathrm{km}^{2}\right)$.

Keadaan topografis Kota Palangka Raya dapat dibedakan dalam 2 (dua) tipe yaitu daerah dataran dan daerah berbukit. Daerah berbukit pada umumnya terdapat di bagian utara Wilayah Kota Palangka Raya dengan ketinggian mencapai > $75 \mathrm{~m}$ dari permukaan laut, dengan titik tertinggi terdapat di daerah Bukit Tangkiling.

\section{Metode Penelitian}


Tahapan pengerjaan penelitian secara garis besar yaitu:

1. Menghitung proyeksi jumlah penduduk Kota Palangka Raya sampai tahun 2037.

2. Menghitung proyeksi jumlah penduduk terlayani

3. Menghitung proyeksi jumlah kebutuhan air bersih terhadap ketersedian air sampai dengan tahun 2037.

\section{Pembahasan}

Analisa Pertumbuhan Penduduk
Penyusunan suatu perencanaan pembangunan, kependudukan merupakan faktor penting karena pembangunan dilakukan dan ditujukan untuk kepentingan penduduk sendiri. Demikian juga dengan perencanaan air bersih, peningkatan jumlah penduduk mempengaruhi peningkatan kebutuhan fasilitas termasuk peningkatan pelayanan air bersih.

4. Untuk luas wilayah, jumlah penduduk dan kepadatan penduduk Kota Palangka Raya dapat dilihat pada Tabel .1 di bawah ini:

Tabel 1. Jumlah dan Kepadatan Penduduk Kota Palangka Raya Tahun 2016

\begin{tabular}{llll}
\hline Kecamatan & $\begin{array}{l}\text { Luas Daerah } \\
\left(\mathbf{K m}^{2}\right)\end{array}$ & $\begin{array}{l}\text { Jumlah } \\
\text { Penduduk }\end{array}$ & $\begin{array}{l}\text { Kepadatan } \\
\text { Per } \mathbf{K m}^{2}\end{array}$ \\
\hline Pahandut & 117,25 & 93.874 & 800,8 \\
Sebangau & 583,50 & 17.398 & 29,8 \\
Jekan Raya & 352,62 & 139.312 & 213,46 \\
Bukit Batu & 572,00 & 13.749 & 24,03 \\
Rakumpit & 1053,14 & 3404 & 3,23 \\
& & & \\
\hline Kota Palangkaraya & 2678,51 & 267.757 & 99,96 \\
\hline
\end{tabular}

Sumber: Buku Statistik Kota Palangka Raya

a. Jumlah PendudukData jumlah penduduk Kota Palangka Raya di dalam Angka Tahun 2007-2016. Data
Jumlah Penduduk Kota Palangka Raya dapat dilihat pada Tabel

Tabel .2. Data Jumlah Penduduk Jangka Waktu 10 Tahun Terakhir

\begin{tabular}{cc}
\hline Tahun & Jumlah Penduduk (jiwa) \\
\hline 2007 & 188.123 \\
2008 & 191.014 \\
2009 & 200.998 \\
2010 & 220.962 \\
2011 & 224.663 \\
2012 & 229.599 \\
2013 & 244500 \\
2014 & 252105 \\
2015 & 259.865 \\
2016 & 267757 \\
\hline
\end{tabular}

b. Proyeksi Jumlah Penduduk

Persentase pertumbuhan penduduk Kota Palangka Raya selama 2012-2016 adalah

$$
\begin{aligned}
& r=\left(\frac{Z\left(P_{2}-P_{1}\right)}{\left(T 2-T_{1}\right)}\right) \times 100 \%
\end{aligned}
$$

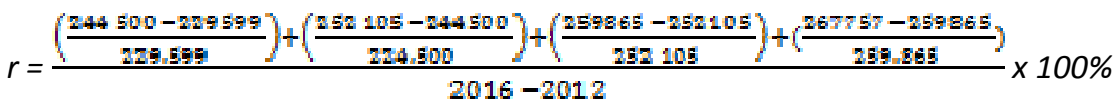

$$
\begin{aligned}
& r=\frac{0,091+0,034+0,031+0,027}{4} \times 100 \% \\
& r=3,998 \%
\end{aligned}
$$




\section{Metode Least Square}

Perhitungan proyeksi jumlah penduduk Kota Palangka Raya. Dengan metode Least Square dilakukan dengan menggunakan persamaan:

$$
\begin{aligned}
& y=a+b x \\
& a=\frac{(\Sigma \mathrm{Yi})\left(\Sigma x i^{2}\right)-(\Sigma x i)(\Sigma x i Y i)}{(N)\left(\Sigma x i^{2}\right)-(\Sigma x i)^{2}} \\
& b=\frac{(N)(\Sigma x i Y i)-(\Sigma x i)(\Sigma Y i]}{(N)\left(\Sigma x i^{2}\right)-(\Sigma x i)^{2}}
\end{aligned}
$$

\section{Keterangan:}

$\mathrm{y}=$ peubah/variable tidak bebas (dimana $y=p)$

$a \& b=$ nilai dari perhitungan berdasarkan data penelitian

$\mathrm{x}=$ peubah/variable bebas atau predictor

$\mathrm{N} \quad=$ jumlah data

Proyeksi jumlah penduduk Kota Palangka Raya dari tahun 2017 sampai 2027, menggunakan metode Least Square dapat dilihat pada Tabel .4

Tabel 4. Proyeksi Penduduk Dari 2017-2037 Per 5 Tahun

dengan Metode Least Square

\begin{tabular}{ccc}
\hline No. & Tahun & Jumlah \\
\hline 1 & 2017 & 277.802 \\
2 & 2022 & 322.641 \\
3 & 2027 & 367.480 \\
4 & 2032 & 412.319 \\
5 & 2037 & 457.158 \\
\hline \multicolumn{3}{c}{}
\end{tabular}

Proyeksi penduduk dari 2017-2037 per 5 tahun

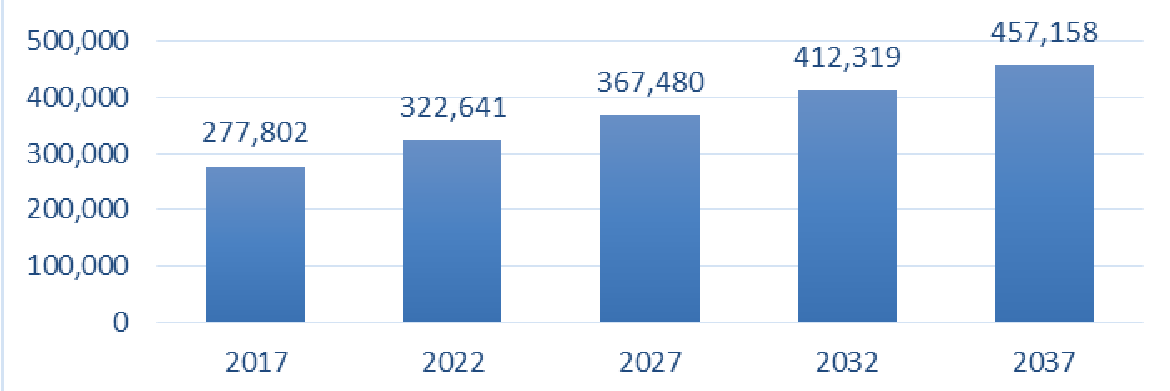

Gambar .1. Grafik Proyeksi penduduk Tahun 2017-2037 Per Lima Tahun

Dari hasil perhitungan dengan Metode Least Square untuk proyeksi jumlah penduduk Kota Palangka Raya dari tahun 2017-2037 didapat proyeksi jumlah penduduk pada tahun 2037 sebesar 457.158 jiwa.

\section{Faktor Kebutuhan Air per Orang per Hari}

1. Kebutuhan Air Domestik

Pelayanan air bersih penduduk untuk kepentingan rumah tangga dilakukan dengan 2 sistem, yaitu sambungan rumah (SR) dan sambungan hidran umum (HU). Tingkat konsumsi air rata-rata yang harus dicapai pada tahun 2017 adalah sebesar 130 liter/org/hari untuk sambungan rumah.

Perhitungan kebutuhan air domestik tahun 2017:

a. Jumlah penduduk terlayani = Jumlah Penduduk $\mathrm{x}$ $\%$ cakupan layanan

$$
\begin{aligned}
& =277,802 \times 35,99 \% \\
& =81.986 \text { jiwa }
\end{aligned}
$$

b. Jumlah penduduk terlayani sambungan langsung (SR)

Jumlah terlayani $(\mathrm{SR}) \quad=80 \% \times$ jumlah $\quad=n d u d u k$ terlayani

$$
\begin{aligned}
& =80 \% \times 81.986 \\
& =65.589 \text { jiwa }
\end{aligned}
$$

C. Kebutuhan air perkapita sambungan langsung (SR) Kebutuhan (SR) $\quad=130 \times$ jumlah terlayani

$$
\begin{aligned}
& =130 \times 65.589 \\
& =8.526 .538 \text { liter/hari/orang } \\
& =98,69 \text { liter/detik/orang }
\end{aligned}
$$

d. Jumlah penduduk terlayani 98,69 liter/detik hidran umum (HU)

Jumlah terlayani $(\mathrm{HU}) \quad=20 \% \times$ jumlah penduduk terlayani 


$$
\begin{aligned}
& =20 \% \times 81.986 \\
& =16.397 \text { jiwa }
\end{aligned}
$$

e. Kebutuhan air melalui hidran umum (HU) Kebutuhan (SR) $=30 \times$ jumlah terlayani (HU)

$$
\begin{aligned}
& =30 \times 16.397 \\
& =491.916 \text { liter/hari } \\
& =5,69 \text { liter/detik }
\end{aligned}
$$

f. Total kebutuhan air domestic $=$ Kebutuhan $(S R)+$ kebutuhan (HU)

\begin{tabular}{|c|c|c|c|c|c|c|c|}
\hline \multirow{2}{*}{ No. } & \multirow{2}{*}{ Deskripsi } & \multirow{2}{*}{ Satuan } & \multicolumn{5}{|c|}{ Tahun } \\
\hline & & & 2017 & 2022 & 2027 & 2032 & 2037 \\
\hline 1 & Jumlah penduduk tahun & jiwa & 227.802 & 322.641 & 367.480 & 412.319 & 457.158 \\
\hline 2 & Cakupan pelayanan & $\%$ & 35,99 & 45 & 55 & 65 & 80 \\
\hline 3 & Jumlah penduduk terlayani & jiwa & 81.986 & 145.188 & 202.114 & 268.007 & 365.726 \\
\hline 4 & $\begin{array}{l}\text { Jumlah penduduk terlayani } \\
\text { (sambungan langsung ) }\end{array}$ & jiwa & 65.589 & 116.151 & 161.691 & 214.406 & 292.581 \\
\hline 5 & $\begin{array}{l}\text { Kebutuhan air perkapita } \\
\text { (sambungan langsung) }\end{array}$ & $\begin{array}{l}\text { liter/kapita } \\
\text { /hari }\end{array}$ & 130 & 130 & 130 & 130 & 130 \\
\hline 6 & $\begin{array}{l}\text { Kebutuhan air melalui } \\
\text { sambungan langsung (SR) }\end{array}$ & liter/detik & 98,69 & 174,76 & 243,29 & 322,60 & 440,23 \\
\hline 7 & $\begin{array}{l}\text { Jumlah penduduk terlayani } \\
\text { (kran umum) }\end{array}$ & jiwa & 16.397 & 29.038 & 40.423 & 53.601 & 73.145 \\
\hline 8 & $\begin{array}{l}\text { Kebutuhan air perkapita } \\
\text { (kran umum) }\end{array}$ & liter/kapita/hari & 30 & 30 & 30 & 30 & 30 \\
\hline 9 & $\begin{array}{l}\text { Kebutuhan air melalui kran } \\
\text { umum }\end{array}$ & liter/detik & 5,69 & 10,08 & 14,04 & $18,61^{`}$ & 25,40 \\
\hline 10 & Total kebutuhan domestik & liter/detik & 104,38 & 184,85 & 257,32 & 341,21 & 465,62 \\
\hline
\end{tabular}

$$
\begin{aligned}
& =98,69 \text { liter } / \text { detik + 5,69 liter } / \text { detik } \\
& =104,38 \text { liter } / \text { detik }
\end{aligned}
$$

Selanjutnya perhitungan kebutuhan air domestik Kota Palangka Raya dapat dilihat pada Tabel 5 .

Tabel 5. Hasil Perhitungan Kebutuhan Air Bersih Domestik

\section{Keterangan:}

Cakupan pelayanan eksisting pada 2017 adalah 35,99\%, direncanakan mencapai 80\% pada Tahun 2037. domestik. Sedangkan berdasarkan pengalaman konsumsi air untuk distribusi atau komersil hanya sebesar 5\%-10\% dari total kebutuhan domestic

1. Kebutuhan Air Non Domestik

Sesuai dengan kebutuhan air untuk non domestik maksimum sebesar $30 \%$ dari total kebutuhan air untuk

Tabel 6. Hasil Perhitungan Kebutuhan Air Bersih Non domestik

\begin{tabular}{rlrrrrr}
\hline No. & \multicolumn{1}{c}{$\begin{array}{c}\text { Jenis } \\
\text { Fasilitas }\end{array}$} & Jumlah & Satuan & Kebutuhan & Satuan & $\begin{array}{c}\text { Jumlah } \\
\text { Pemakaian } \\
\text { (liter/hari) }\end{array}$ \\
\hline 1 & Sekolah & 58.218 & orang & 10 & liter/murid/hari & 582.180 \\
2 & Rumah Sakit & 777 & bed & 200 & liter/bed/hari & 155.000 \\
3 & Puskesmas & 44 & unit & 2.000 & liter/hari & 88.000 \\
4 & Kantor & 5834 & orang & 10 & liter/pegawai/hari & 58.340 \\
5 & Hotel & 84 & bed & 150 & liter/hari/bed & 12.600 \\
6 & Masjid & 176 & unit & 3.000 & liter/hari/unit & 528.000 \\
\end{tabular}




\begin{tabular}{|c|c|c|c|c|c|c|}
\hline 7 & Mushola & 235 & Unit & 2000 & liter/hari/unit & 470.000 \\
\hline 8 & Pasar & 10 & ha & 12.000 & liter/detik/ha & 120.000 \\
\hline 9 & Rumah Makan & 550 & sit & 100 & liter/hari/sit & 55.000 \\
\hline & \multirow{2}{*}{\multicolumn{4}{|c|}{ Jumlah }} & liter/hari & 2.069 .520 \\
\hline & & & & & liter/detik & 23,9 \\
\hline
\end{tabular}

\section{Faktor Fluktuasi Pemakaian Air}

Fluktuasi kebutuhan pemakaian air dimaksudkan sebagai pemakaian air yang tidak merata untuk setiap satuan waktu yang besar atau kecilnya pemakaian air oleh konsumen sangat bervariasi.

Perhitungan kebutuhan air total tahun 2017:

a. Total kebutuhan air domestik 104,38 liter/detik

b. Total kebutuhan air non domestik liter/detik

c. Persentase kebutuhan air non domestik terhadap kebutuhan air domestic

$$
\begin{aligned}
& \text { Persentase \% }=\frac{\text { kebutuhan air non domegtik }}{\text { kebutuhan air domegtik }} \times 100 \% \\
& \qquad \begin{array}{r}
104,38 \mathrm{liter} / \text { detik } \\
=22,9 \%
\end{array}
\end{aligned}
$$

d. Total kebutuhan air = kebutuhan air domestik + kebutan air non domesitk $=104,38$ liter/detik $+23,9$ liter/detik

$=128,28$ liter $/$ detik

e. Persentase kehilangan air $=20 \%$

Total kebutuhan air rata-rata $=$ Total kebutuhan air + jumlah kehilangan air

$=127,06$ liter $/$ detik $+(20 \% \times 127,06)$

$=153,9$ liter $/$ detik

f. Faktor hari maksimum (fmd) $\quad=110 \%$

g. Kebutuhan air hari maximum $=(\mathrm{fmd}) \mathrm{x}$

total kebutuhan air rata-rata

$$
=110 \% \times 153,9 \text { liter } / \text { detik }
$$$$
=169,3 \text { liter } / \text { detik }
$$

h. Faktor hari maksimum (fmd) $\quad=150 \%$

i. Kebutuhan air hari maximum jam puncak $=(\mathrm{fmd}) \mathrm{x}$ total kebutuhan air rata-rata $=150 \% \times 169,3$

$=253,9$ liter $/$ detik

\begin{tabular}{|c|c|c|c|c|c|c|c|}
\hline \multirow[t]{2}{*}{ No. } & \multirow[t]{2}{*}{ Deskripsi } & \multirow[t]{2}{*}{ Satuan } & \multicolumn{5}{|c|}{ Tahun } \\
\hline & & & 2017 & 2022 & 2027 & 2032 & 2037 \\
\hline 1 & Total kebutuhan domestik & liter/detik & 104,38 & 184,85 & 257,32 & 341,21 & 465,62 \\
\hline 2 & $\begin{array}{l}\text { Total kebutuhan non } \\
\text { domestik }\end{array}$ & liter/detik & 23,90 & 27,73 & 38,60 & 51,18 & 69,84 \\
\hline 3 & $\begin{array}{c}\text { Total kebutuhan air } \\
\text { (domestik + non domestik) }\end{array}$ & liter/detik & 128,30 & 212,50 & 295,90 & 392,30 & 535,40 \\
\hline 4 & Kehilangan air & $\%$ & 20,00 & 20,00 & 20,00 & 20,00 & 20,00 \\
\hline 5 & Kebutuhan air bersih rata- & liter/detik & 153,94 & 255,09 & 355,10 & 470,87 & 642,56 \\
\hline 6 & $\begin{array}{l}\text { Faktor kebutuhan hari } \\
\text { maksimum }\end{array}$ & - & 1,10 & 1,10 & 1,10 & 1,10 & 1,10 \\
\hline 7 & Kebutuhan air hari & liter/detik & 169,33 & 280,60 & 390,61 & 517,96 & 706,81 \\
\hline 8 & Faktor kebutuhan puncak & & 1,50 & 1,50 & 1,50 & 1,50 & 1,50 \\
\hline 9 & $\begin{array}{c}\text { Kebutuhan air bersih } \\
\text { puncak }\end{array}$ & liter/detik & 254,0 & 420,9 & 585,9 & 776,9 & 1060,2 \\
\hline
\end{tabular}

Hasil perhitungan kebutuhan air Total Kota Palangka Raya selengkapnya dapat dilihat pada Tabel 7.

Tabel 7. Hasil Perhitungan Kebutuhan Air Bersih Total Kota Palangka Raya

Nilai kebutuhan air bersih yang diambil adalah kebutuhan air bersih pada jam puncak yaitu 1060,2 liter/detik karena nilai tersebut merupakan nilai kebutuhan air maksimal yang harus terpenuhi agar masyarakat Kota Palangka Raya terlayani secara maksimal.

\section{Sumber Air Baku Air Minum}

Kota Palangka Raya memiliki sumber air baku yang besar, baik yang bersumber dari air tanah maupun air permukaan. Hal tersebut menyebabkan masyarakat pada umumnya tidak mengalami kesulitan dalam penyediaan 
air bersih. Sungai Kahayan merupakan pemasok sumber air baku PDAM Kota Palangka Raya yang memiliki debit cukup besar ( $Q$ maks) $1261 \times 10^{6} \mathrm{~m}^{3} /$ tahun atau 40 $\mathrm{m}^{3} /$ detik dengan debit rata-rata (Q rata-rata) $20 \mathrm{~m}^{3} /$ detik dan debit minimum ( $Q$ min) sebesar $4 \mathrm{~m}^{3} /$ detik namun kualitasnya sungai terpengaruh pada kondisi lingkungan.
PDAM Kota Palangka Raya memanfaatkan Sungai Kahayan sebagai sumber air baku air minum dengan potensi air di wilayah Sungai Kahayan yaitu rata-rata $837,81 \mathrm{~m}^{3} /$ detik atau setara dengan 26,4 milyar $\mathrm{m} 3$ per tahun yang terbagi dalam Tabel IV.8 dibawah ini:

Tabel 8 Potensi Air Wilayah Sungai/ DAS Kahayan

\begin{tabular}{lcccc}
\hline No. & Nama DAS /SUB DAS & $\begin{array}{c}\text { Potensi } \\
\text { ( Juta } \mathrm{m}^{3} / \text { Tahun) }\end{array}$ & $\begin{array}{c}\text { Potensi } \\
\mathrm{m}^{3} / \text { detik }\end{array}$ & Prosentase \\
\hline & Kahayan & $9.366,80$ & 297,02 & $35,45 \%$ \\
2. & Manuhing & $5.132,46$ & 162,75 & $19,43 \%$ \\
3. & Paduran & $1.937,74$ & 61,45 & $7,33 \%$ \\
4. & Hilir sebangau & $1.916,13$ & 60,76 & $7,25 \%$ \\
5. & Hilir kahayan & $4.276,59$ & 135,61 & $16,19 \%$ \\
6. & Sebangau & $3.791,28$ & 120,22 & $14,35 \%$ \\
& Jumlah & $26.421,00$ & 837.81 & $100 \%$ \\
\hline
\end{tabular}

(RISPAM Palangka Raya, 2013)

Sungai Kahayan telah dimanfaatkan sebagai sumber air minum dan telah dikelola oleh Perusaan Daerah Air
Minum Kabupaten Gunung Mas dan PDAM Kota Palangka Raya, seperti ditunjuk pada Tabel 9 di bawah ini.

Tabel 9. Pemanfaatan Sungai Kahayan Sebagai Sumber Air Baku Air Minum

\begin{tabular}{|c|c|c|c|c|}
\hline No & Sumber Air & $\begin{array}{c}\text { Sistem } \\
\text { Pengelolaan }\end{array}$ & $\begin{array}{c}\text { Kapasitas } \\
\text { (L/det) }\end{array}$ & lokasi \\
\hline \multicolumn{5}{|c|}{ Kabupaten Gunung Mas } \\
\hline 1 & Sungai Kahayan & IPA lengkap & 5.0 & Kecamatan Kurun \\
\hline 2 & Sungai Kahayan & IPA lengkap & 5.0 & Kecamatan Teweh \\
\hline 3 & Sungai Kahayan & IPA lengkap & 2.5 & Kecamatan Sepang \\
\hline 4 & Sungai Kahayan & IPA lengkap & 2.5 & Kecamatan Rungan \\
\hline \multicolumn{5}{|c|}{ Palangka Raya } \\
\hline 1 & Sungai Kahayan & IPA lengkap & 255 & Palangka Raya \\
\hline 2 & Sungai Kahayan & IPA lengkap & 17.5 & Kecamtan Tangkiling \\
\hline
\end{tabular}

(RISPAM Palangka Raya, 2013)

Sumber air yang digunakan untuk sistem penyediaan air bersih adalah Sungai Kahayan dengan $Q$ maksimum $=40$ $\mathrm{m}^{3} /$ det, $\mathrm{Q} \min =4 \mathrm{~m}^{3} /$ det dengan pemakaian PDAM
Gunung mas dan Palangka Raya sebesar 287,5 L/det, maka secara teoritis sumber air baku PDAM masih tersisa $4000 \mathrm{~L} /$ det $-287,5 \mathrm{~L} /$ det $=3712,5 \mathrm{~L} / \mathrm{det}$.

Tabel 10. Skenario Perhitungan Kelebihan dan Kekurangan Debit Air (Jam Puncak) Kota Palangka Raya 2017-2037

\begin{tabular}{|c|c|c|c|c|c|}
\hline \multirow{2}{*}{ Uraian } & \multicolumn{5}{|c|}{ Proyeksi Kebutuhan Air (L/det) } \\
\hline & 2017 & 2022 & 2027 & 2032 & 2037 \\
\hline Palangka Raya & 254,0 & 420,9 & 585,9 & 776,9 & 1060,2 \\
\hline Kapasitas Produksi Eksisting (L/det) & 225 & 225 & 225 & 225 & 225 \\
\hline Shortage(L/det) & 29 & 195,9 & 360,9 & 551,9 & 835,5 \\
\hline Sumber air untuk memenuhi kekurangan sistem (L/det) & 3712,5 & 3712,5 & 3712,5 & 3712,5 & 3712,5 \\
\hline Sisa Kapasitas Sungai Kahayan minimum (L/det) & 3683,5 & 3516,6 & 3351,6 & 3160,6 & 2877 \\
\hline
\end{tabular}




\section{Kesimpulan}

Dari hasil perhitungan dan kajian yang sudah dilakukan pada bab terdahulu, maka dapat ditarik kesimpulan sebagai berikut:

1. Metode yang digunakan untuk memproyeksikan jumlah penduduk di Kota Palangka Raya adalah metode Least Square.

2. Dari perhitungan menggunakan metode Least Squar didapat jumlah penduduk Kota Palangka Raya pada tahun 2037 sebanyak 457.158 jiwa.

3. Menurut perhitungan kebutuhan air total untuk tahun 2017 (254 liter/detik), tahun $2022(420,9 \quad$ liter/detik), tahun $2027 \quad(585,9 \quad$ liter/detik), tahun $2032(776,9$ liter/detik) dan tahun $2037(1060,2$ liter/detik).

4. Sungai Kahayan sebagai sumber penyediaan air bersih masih mampu sampai tahun 2037 yaitu 2877 liter/detik.

\section{DAFTAR PUSTAKA}

[1]. Aceh, D. 2014. 'Air bersih PDAM Tirta Meulaboh ( Studi Kasus Pada Zona Layanan Kecamatan Johan Pahlawan kabupaten Aceh Barat ) TESIS'.

[2]. Agustina, d. V. 2007. 'Analisa Kinerja Sistem Distribusi Air Bersih PDAM Kecamatan Banyumanik Di Perumnas Banyumanik ( Studi Kasus Perumnas Banyumanik kel. Srondol Wetan )TESIS'.

[3]. Badan Pusat Statistik Kota Palangka Raya dalam Angka 2018. DED SPAM Kota Palangka Raya, 2015.

[4]. Mamik, f. A., 2017. Evaluasi Eksisting dan Upaya Perbaikan Pelayanan SPAM PDAM Kota Mojokerto. 397.

[5]. Ray k. Linsley, j. B. F. 1991. Teknik Sumber Daya Air Jilid 1.
[6]. Rezagama, a. 2016. Jaringan pemipaan air minum konsep,teori, aplikasi.

[7]. Riduan, r. 2017. Evaluasi Tekanan Jaringan Distribusi Zona Air Minum Prima. 3(1), 12-20.

[8]. Rispam Palangka Raya, 2013. . Rencana Induk Sistem Penyediaan Air Minum (RISPAM) Kota Palangka Raya 2013.

[9]. Saparina, w. 2017. Penurunan kehilangan Air Di Sistem

[10]. Setiawan, t., \& dr. Ir. Budi Kamulyan, m. E. I. S. S. T. . M. S. . P. 2017. Kajian sistem penyediaan air minum (spam) kampus universitas gadjah mada yogyakarta. 0-1.

[11]. Sofia, e., Riduan, r., \& Abdi, c. (2016). Evaluasi Keberadaan Sisa Klor Bebas di Jaringan Distribusi IPA Sungai Lulut PDAM Bandarmasih. Jukung (Jurnal Teknik Lingkungan).

[12]. Suhardi. (n.d.). Kajian Spasial Tingkat Pelayana Air Bersih Di Perumahan Limbangan Baru Kabupaten Banjarnegara.

[13]. Swamee, p. K., \& sharma, a. K. 2008. Design of water supply pipe networks. In design of water supply pipe networks. Https://doi.org/10.1002/9780470225059

[14]. Walski, t. M., Chase, d. V., \& Savic, d. A. 2001. Water Distribution Modeling. 72.

[15]. Widnyana, i. M. 2018. Open Access [15]. Evaluation And Analysis Of Flow And Pressure Patterns On Water-Pipeline Network Of Regional Clean Water Companytirta Kahayan, Palangkaraya City. (9), 271-27. 